\title{
PERAN PERAWAT PENDIDIK DALAM UPAYA PENCEGAHAN DAN PEMUTUSAN RANTAI PENYEBARAN INFEKSI COVID-19
}

\author{
Nama : Khairun Nisa \\ Email : k.khairunnisa1311@gmail.com
}

\begin{abstract}
Nurses are one of the medical personnel who have an important role in caring for Covid19 patients, who are the most potentially infected with Covid. The high rate of spread, which is increasing day by day, makes the public, medical, and government nervous. The most fatal effect that can be caused by this virus is death. Patients who have a history of chronic diseases such as heart disease have a high potential for infection, and the elderly are also a category of concern. Apart from death and illness, economic factors, soliasl, culture and religion are also affected. The people's economy continued to deteriorate which led to an economic crisis. Therefore, it is necessary to take preventive measures and to break the chain of infection that must be carried out by the whole community and all parties. However, without sufficient knowledge and education, the community will find it difficult to implement the established recommendations and policies. It is for this reason that the public needs to be given an understanding of Covid-19 through education or provision of health education by the authorities. The content of education is in the form of understanding covid-19, the signs and symptoms it causes, prevention, and efforts that can be made so as not to be infected with Covid-19.
\end{abstract}

Key Word : Covid-19, nurse education, infection.

\begin{abstract}
ABSTRAK
Perawat merupakan salah satu tenaga medis yang memiliki peran penting dalam merawat pasien covid-19, yang merupakan pihak yang paling berpotensi terkena infeksi covid. Tingginya angka penyebaran yang semakin hari semakin bertambah membuat masyarakat, medis, dan pemerintah merasa gelisah. Efek yang yang paling fatal yang bisa diakibatkan oleh virus ini adalah kematian. Pasien yang memiliki riwayat penyakit kronis seperti jantung sangat berpotensi tersena infeksi, lansia juga masuk kedalam katerogi yang menghawatirkan. Selain kematian, dan sakit faktor ekonomi, soliasl, budaya serta agama juga menjadi imbasnya. Perekonomian masyarakat terus memburuk yang menyebabkan krisis ekonomi. Oleh karena itu diperlukan tindakan pencegahan dan pemutusan rantai infeksi yang harus dijalankan oleh seluruh masyarakat dan semua pihak. Namun tanpa ilmu dan edukasi yang cukup masyarakat akan kesulitan menerapkan himbauan dan kebijakan yang ditetapkan. Dengan alasan inilah masyarakat perlu diberikan pemahaman tentang covid-19 ini melalui edukasi atau pemberian pendidikan kesehatan oleh pihak yang berwenang. Isi dari edukasi berupa pengertian covid-19, tanda dan gejala yang ditimbulkan, pencegahan, serta upaya yang bisa dilakukan agar tidak terinfeksi covid-19.
\end{abstract}

Kata Kunci : Covid-19, Perawat pendidik, infeksi. 


\section{LATAR BELAKANG}

Virus Corona atau human corona virus merupakan virus yang sangat berbahaya, setidaknya sudah menyebabkan tiga wabah besar penyakit di dunia selama dua dekade terakhir, diantaranya SARS, MERS, dan Covid-19. sejak permulaan tahun 2020, kasus infeksi ini ditemukan mulai dari akhir Desember 2019 di Kota Wuhan, Provinsi Hubei, China dengan kasus kluster pneumonia yang etiologinya belum jelas. Jumlah kasus ini terus bertambah seiring berjalannya waktu, sampai saat ini banyak masyarakat yang terkena infeksi dan sudah banyak yang meninggal. Pada tanggal 30 Januari 2020, World Health Organization (WHO) memutuskan bahwa kasus infeksi Covid-19 ini sebagai Public Health Emergency of International Concern (PHEIC) / Kedaruratan Kesehatan Masyarakat Yang Meresahkan Dunia (KKMMD) (CDC, 2020).

Pada tanggal 11 Maret 2020, World Health Organization (WHO) juga menetapkan Covid-19 sebagai pandemi. Disebut pandemi Karena wabah yang berjangkit serempak di mana-mana, meliputi daerah geografis yang begitu luas. Secara umum, penularan palin cepat antar virus Corona dengan manusia yaitu melalui droplet atau cairan yang dikeluarkan oleh sipengidap saat batuk atau bersin serta yang menempel di benda sekitar. Penularan antarmanusia yang terjadi dengan masif membuat pembatasan jarak dan sosial harus dilakukan dengan ketat. Sampai saat ini terdapat 65 negara yang terinfeksi virus corona. Terhitung per tanggal 29 April 2020 jumlah penderita yang terinfeksi Covid-19 di dunia mencapai 3,1 juta orang (WHO, 2020).

Sejauh ini masi banyak masyarakat yang belum paham tentang gejala infeksi virus Corona yang mirip dengan penyakit flu. Tanda dan gejala umum infeksi COVID19antara lain gejala gangguan pernapasan akut seperti demam, batuk dan sesak napas. Masa inkubasi rata-rata 5-6 hari dengan masa inkubasi terpanjang 14 hari. Pada kasus COVID-19yang berat dapat menyebabkan pneumonia, sindrom pernapasan akut, gagal ginjal, dan bahkan kematian. Tanda dan gejala umum infeksi COVID-19antara lain gejala gangguan pernapasan akut seperti demam, batuk dan sesak napas. Masa inkubasi rata-rata 5-6 hari dengan masa inkubasi terpanjang 14 hari. Pada kasus COVID-19 yang berat dapat menyebabkan pneumonia, sindrom pernapasan akut, gagal ginjal, dan bahkan kematian.

Tanda-tanda dan gejala klinis yang dilaporkan pada sebagian besar kasus adalah demam, dengan beberapa kasus mengalami kesulitan bernapas, dan hasil rontgen menunjukkan infiltrat pneumonia luas di kedua paru. beberapa kasus mengalami hilangnya penciuman dan Indra perasa. 
Kewaspadaan didalam masyarakat belum terbangun sepenuhnya. Bahkan masih banyak masyarakat yang belum percaya dengan keberadaan covid-19 tersebut. Pola pikir yang menganggap remeh ini yang membuat pemerintah dan medis kesulitan dalam mengendalikan penularan infeksi. Faktor yang bisa menyebabkan masyarakat tidak mengindahkan himbauan serta aturan yang ditetapkan tersebut dikarenakan masyarakat mendapatkan inovasi dan modifikasi dalam pemberian atau penyampaian informasi dari pemerintah dan pihak medis, mereka hanya mendengarkan

\section{METODE}

Penulisan ini menggunakan metode literature review dengan pendekatan jurnal yang relevan dan akurat serta berfokus pada edukasi masyarakat dalam upaya

\section{HASIL}

Manfaat dari edukasi atau pendidikan kesehatan yang dilakukan oleh perawat yaitu untuk membuka wawasan masyarakat terkait covid-19, tujuan dari edukasi ini adalah untuk merubah perilaku masyarakat dan persepsi yang tidak benar tentang covid-19, stigma dan asusmsi yang tidak benar yang beredar di masyarakat harus diluruskan agar masyarakat tidak salah mempersepsikan covid-19. Masih banyak masyarakat yang belum mempercayai adanya infeksi ini dan banyak pula masyarakat yang memiliki pendapat tersendiri yang belum tentu jelas mitos mitos yang beredar di masyarakat saja, hal itu yang menyebabkan para masyarakat tidak mau patuh dan tidak mempercayai adanya covid-19 tersebut dengan begitu infeksi ini akan terus menjadi ancaman yang semakin hari semakin meluas, dan akan terus berdampak pada aspek politik, perekonomian masyarakat, sosial, budaya, pertahanan, dan keamanan, serta kesejahteraan masyarakat diIndonesia, oleh karena itu diperlukan strategi yang efektif dalam agar cepat dalam masalah penanganan covid-19v tersebut.

pencegahan dan pemutusan mata rantai penyebaran infeksi. Tujuan dari pengkajian ini adalah untuk memperluas wawasan terkait manfaat edukasi bagi masyarakat dalam upaya pemutusan rantai infeksi covid19.

kebenarannya, banyak dari masyarakat yang sakit tidak mau kerumah sakit karena takut dinyatakan positif covid-19, bahkan banyak juga yang belum mengetahui gejala dari infeksi ini karena sangat mirip dengan flu. Oleh karena itu, disinilah para perawat pendidik memberikan dan meluruskan pemahaman tersebut. Perawat akan membantu masyarakat mencegah penularan yang diakibatkan oleh covid-19 melalui balai edukasi dan seminar dengan bantuan media zoom dan live YouTube. Materi yang akan dibawakan akan membantu masyarakat memahami bahaya yang bisa diakibatkan 
oleh infeksi ini dengan begitu masyarakat akan mau mengindahkan himbauan yang telah dibuat. Upaya yang bisa dilakukan perawat dalam memutus rantai penyebaran infeksi yaitu dengan mengajarkan cara mencegah infeksi seperti memakai masker, mencuci tangan, menjaga jarak, dan menjaga imunitas tubuh. Peran masyarakat

\section{PEMBAHASAN}

Perawat sebagai tenaga kesehatan yang berada di garda terdepan yang paling sering kontak dengan pasien memiliki risiko Sangat tinggi tertular virus Covid -19 . Perawat adalah salah satu tenaga kesehatan dengan jumlah besar dalam pusat pelayanan kesehatan, bekerja secara langsung dan terus kontak dengan pasien selama 24 jam. Tingginya risiko penularan penyakit tersebut menimbulkan perawat harus terjun ke masyarakat untuk memberikan himbauan dan pendidikan kesehatan tentang Covid-19. Pendidikan kesehatan ini tujuannya agar infeksi yang terjadi tidak terus terusan bertambah karena berdampak besar bagi perawat, pihak medis lainnya, masyarakat, dan paling dikhawatirkan pada lansia dan masyarakat dengan penyakit kronis. Hal ini dapat mempengaruhi penampilan perawat dalam merawat pasien, sebelum melangsungkan pendidikan kesehatan pada perawat pendidik harus mempersiapan diri sedini mungkindalam bentuk meningkatkan pengetahuan dan keterampilan merawat pasien Covid-19 akan berdampak positif dalam mengatasi ketakutan serta permasalahan yang sering timbul dalam merawat pasien Covid-19, dan menghadapi masyarakat yang belum mendapatkan sangat penting dalam upaya pemutusan rantai infeksi, dengan adanya kemauan dan kerjasama masyarakat ini akan membuat negeri mudah melawan covid-19.

edukasi. Tujuan akhir dari kegiatan edukasi (pendidikan kesehatan) yaitu meningkatkan kesejahteraan, kesehatan masyarakat, mengehentikan infeksi dan meningkatkan mutu pelayanan keperawatan secara optimal. Perawat harus disiplin dan patuh agar tujuan dari edukasi ini dapat tercapai. Karena dengan ketidak patuhan dalam melakukan upaya pencegahan penularan virus corona akan meningkatkan resiko untuk tertular penyakit.

Kelompok lansia memiliki tingkat risiko tinggi saat terjadi wabah penyakit.Tingkat imunitas seseorang berperan dalam penentuan Besarnya potensi infeksi seseorang. Selain kaum lansia, orang dengan penyakit bawaan juga memiliki peluang yang serupa. Untuk mencegah penularan virus Corona perlu dilakukan peningkatan pengetahuan melalui pendidikan kesehatan. Manfaat pendidikan kesehatan ini adalah untuk menambah pengetahuan masyarakat.

\section{Upaya yang bisa dilakukan masyarakat agar terhindar dari covid-19 antara lain:}

1. Menjaga daya tahan tubuh (imunitas) untuk senantiasa sehat dan kuat adalah usaha yang paling penting dalam mencegah 
infeksi dan penyakit. Apabila individu dan masyarakat memiliki imunitas yang baik, tubuh tidak akan mudah terjangkit penyakit , imun yang kuat akan melawan patogen sumber infeksi, Yang akhirnya tubuh akan terhindar dari sakit. Mengonsumsi makanan bergizi, istirahat yang cukup dan sering berolahraga Adalah kegiatan yang efektifdalam meningkatkan daya tahan tubuh. Individu dengan defisiensi nutrisi, kurang istirahat, dan tidak melakukan kegiatan fisik (olahraga) secara teratur memiliki peningkatan risiko untuk mengalami infeksi covid-19

2. Mencuci tangan dengan sabun pada air mengalir selama atau menggunakan handsaitizer berbahan dasar alkohol dapat menghentikan penyebaran infeksi melalui sentuhan. waktu yang dianjurkan untuk mencuci tangan pada masa pandemi ini diantaranya yaitu setelah menyentuh fasilitas umum yang mungkin disentuh oleh orang lain, seperti gagang pintu, railing tangga, dan meja, setelah berkontak dengan hewan, serta sebelum menyentuh mata, hidung, dan mulut

\section{Memakai masker}

sebelum mengambil masker diharuskan mencuci tangan menggunakan sabun terlebih dahulu, memastikan bahwa pemakaian masker menutupi mulut dan hidung, hindari memegang masker ketika digunakan, dan tidak menyentuh bagian depan masker saat mengganti (WHO, 2020). Pemakaian masker wajah dan mencuci tangan secara teratur merupakan dua cara utama untuk membantu mencegah penularan virus corona. Namun memakai masker wajah dan mecuci tangan secara teratur belum cukup menghentikan penularan virus corona. Upaya penting lainnya agar tidak tertular virus corona ialah menerapkan physical distancing atau dikenal juga dengan social distancing

\section{Social Distancing tidak hanya terbatas} dari menjaga jarak dan menghindari kontak langsung dengan orang lain, namun juga mencakup strategi untuk mebatasi risiko infeksi di dalam ruangan. Upaya yang dapat dilakukan untuk mengendalikan penularan infeksi virus corona di dalam ruangan diantaranya yaitu menyediakan ventilasi yang cukup yang ditingkatkan dengan penyaringan partikel dan desinfeksi udara, menghindari resirkulasi udara dan menghindari kepadatan berlebih

Edukasi ini akan dilakukan dengan 2 metode, yang pertama melalui melalui media seperti YouTube, seminar Zoom, atau quesioner, dan yang kedua secara langsung. Dengan metode pertama sasaran audience bisa lebih luas, metode ini menggunakan media yang tidak perlu mengadakan perkumpulan. Di tahap ini para perawat akan merencanakan waktu pelaksanaaan promosi kesehatan, menentukan media yang mudah dipahami oleh masyarakat. Sebelum audience login ke Zoom atau Live Youtube, para peserta harus mendaptar dan mengisi quesioner terlebih dahulu sebagai syarat masuk ke laman zoom dan live YouTube. Kemudian akan dilanjutkan dengan Pemberian edukasi pendidikan kesehatan terkait covid-19. 
Edukasi akan dilakukan dengan menggunakan media yang bisa membantu masyarakat lebih paham dengan materi ini, dia yang digunakan berupa video animasi, leaflet, serta berita perkembangan covid-19 terkini. Kemudian edukasi dengan teknik kedua yaitu secara langsung, kegiatan yang dilakukan akan sama seperti metode pertama, yang mbedakan hanya tekniknya saja, dengan teknik langsung para perawat akan membagi audience menjadi beberapa kelompok dan membagi waktu agar terhindar dari kerumunan yang berlebihan, protokol kesehatan akan tetap dijalankan, acara ini mewajibkan peserta memakai masker, dan saat pertama masuk para audience harus mencuci tangan di tempat yang telah disediakan, kemudian lanjut mengukur suhu tubuh, dan duduk di kursi yang sudah di atur jaraknya. Para audience tidak dibenarkan duduk secara rapat dan dilarang membuka masker. Pemateri juga memaksimalkan waktunya supaya masyarakat tidak jenuh dan gerah dengan masker tersebut. Dan diakhir acara akan

\section{PENUTUP}

Pemberian edukasi (pendidikan kesehatan) ini dilakukan oleh perawat dengan tujuan suapaya masyarakat tau, mampu, dan mau mengaplikasikan edukasi yang telah diberikan. Tujuan dan harapan dari pemberian penkes ini yaitu supaya kita mampu memutus mata rantai penularan covid-19. Masyarakat yang belum mendapatkan edukasi terkait covid-19 akan sulit menerapkan protokol kesehatan sebab mereka belum paham tujuan dari himbauan tersebut. Dengan menghadiri edukasi ini diadakan acara pembagian masker oleh petugas untuk audience yang hadir. Selama kegiatan berlangsung juga pemateri akan mempersilahkan audience untuk bertanya supaya kita mampu menilai hal apa yang menjadi keluhan dan masalah yang dialami oleh audience.

Di akhir sesi materi para pemateri akan memberi beberapa pertanyaan terkait materi yang telah di sampaikan, tujuannya agar kita tahu sejauh mana audience memahami apa yang di sampaikan dan diharapkan masyarakat mau dan mampu menerapkan pendidikan kesehatan dalam kehidupan sehari-hari agar penyebaran infeksi covid-19 mampu kita hentikan. Keberhasilan pemutusan rantai infeksi akan berhasil apabila masyarakat paham, mampu dan mau menerapkan anjuran yang telah diberikan. Kerjasama dan kesadaran masyarakat sangat berperan penting dalam melindungi dan memperbaiki negeri.

masyarakat bisa waspada dan mampu melindungi orang-orang sekitar. Dari tindakan kecil ini akanbuahkan hasil yang besar bagi negeri, tindakan ini akan saling menguntungkan, mengapa demikian? Karena dengan kesadaran masyarakat yang mampu memutus mata rantai infeksi akan mbuat negeri aman dan sehat, dengan begitu covid akan segera pergi dan ekonomi, sosial dan aktivitas masyarakat bisa kembali normal. 


\section{REFERENSI}

Kusuma,Henni., Zulfa,Fatia. (2020).Upaya Program Balai Edukasi Corona Berbasis Media Komunikasi Dalam Pencegahan Penyebaran Covid-19.Jurnal Abdimas Kesehatan Perintis. 2(1):17-24.

Refialdinata, Jeki. (2020). Analisis Upaya Pencegahan Covid-19 Pada Masyarakat Kampus. Babul Ilmi_Jurnal Ilmiah Multi Science Kesehatan. 12(2):58-68.

Utama.,T.,A. (2020).Pengalaman Perawat Dalam Memberikan Asuhan Keperawatan Pada Pasien Terinfeksi Covid - 19 .Jurnal Ilmu Keperawatan Indonesia (JIKPI).1(2):13-19.Siregar, Rinco.,dkk. (2020). Edukasi Tentang Upaya Pencegahan COVID-19 Pada Masyarakat di Pasar Sukaramai Kecamatan Medan Area Tahun 2020. Jurnal Abdimas Mutiara. 1(2):191-198.

Purba., P.,S.,M.,H. (2021).Implementasi Undang-Undang Nomor 6 Tahun 2018 Tentang Kekarantinaan Kesehatan di Jawa Timur Menghadapi Pandemi Covid 19.Jurnal Pahlawan. 4(1):1-11.

Quyumi,Elfi. Alimansur, M. (2020).Upaya Pencegahan Dengan Kepatuhan Dalam Pencegahan Penularan Covid-19 Pada Relawan Covid.4(1):81-87

Yanti,Etri.,dkk. Mencegah Penularan Virus Corona.Jurnal Abdimas Saintika. 2(1):33-39. 